\title{
Domestication of Blue Swimming Crab for Sustainability: Growth and Genetic Change
}

\author{
Yushinta Fujaya ${ }^{1}$, Andi Aliah Hidayani ${ }^{1}$, Asmi Citra Malina A.R. Tassakka ${ }^{1}$ and \\ Umi Kalsum ${ }^{1}$
}

\begin{abstract}
Blue swimming crabs (Portunus pelagicus) are a fisheries resource which is currently threatened by overexploitation. Crab culture is one approach which can contribute towards sustainable use of blue swimming crab (BSC) populations. In this context, BSC domestication is considered necessary. The purpose of this study was to evaluate the genetic and growth changes occurring during initial stages of a BSC domestication program. The DNA of selected strains was examined using Random Amplified Polymorphism DNA (RAPD). Five OPA primers were used to generate a fragment pattern from the samples collected. The RAPD results showed that BSC domestication combined with selection for fast growth resulted in genetic change, with a genetic distance of $0.1053-0.3158$ between $1^{\text {st }}$ and $4^{\text {th }}$ generations. This distance was associated with significantly higher growth rates after the $4^{\text {th }}$ generation. After 100 days grow-out, mean growth in carapace width was $103 \mathrm{~mm}$ for $1^{\text {st }}$ generation crabs and $109 \mathrm{~mm}$ in the $4^{\text {th }}$ generation, with respective growth rates of $1.0 \mathrm{~mm} /$ day and $1.1 \mathrm{~mm} /$ day. Domestication with selection of fast growing individuals as BSC broodstock resulted in a positive shift towards DNA characteristics associated with faster growth in subsequent BSC generations.
\end{abstract}

Keywords: Blue swimming crab, Sustainability, Domestication, Selective breeding, Growth rate, RAPD

\section{Introduction}

The blue swimming crab (Portunus pelagicus) is a globally important fisheries resource. In Indonesia, this crab is found in most coastal waters within the archipelago, but in recent years indications of over-exploitation have been reported (Hidayani et al., 2015; Fujaya et al., 2016 a, b; La Sara., 2017). Indicators include a decline in both the size of crabs caught and the catch volume. To safeguard this crab population, the Indonesian government has issued regulations setting a minimum allowable capture size.

In Cockburn Sound, Western Australia, the reported decline in crab catches since 2000 resulted in closure of the crab fishery in December 2006 (Johnston et al., 2011). Kunsook et al (2014) also reported an exploitation rate of 0.71 , higher than the optimal value of 0.38, at Kung Krabaen Bay, in the eastern Gulf of Thailand. They also reported a decrease in the size of mature females from $8.10 \pm 0.39 \mathrm{~cm}$ to $7.52 \pm 1.14 \mathrm{~cm}$. Based on these results, Kunsook et al (2014) proposed a sustainable management program for P. pelagicus.

Efforts to domesticate this crab have been initiated by Trijuno et al. (2015) and Fujaya et al (2016b), in order to help maintain the blue swimming crab as a sustainable seafood resource. They have succeeded in breeding $P$. pelagicus seed in a hatchery and raising them in ponds. Growth rates are quite good and the meat of the pond-reared crabs can meet export quality standards.

This study aimed to evaluate the changes resulting from domestication followed by selective breeding for rapid growth in terms of population genetics and growth rate. The

| ${ }^{1}$ Fisheries Department, Faculty of Marine Science and Fisheries, Hasanuddin University, Kampus Tamalanrea Makassar 90245, Indonesia 
genetic distance between domesticated crab generations ( $1^{\text {st }}$ and $4^{\text {th }}$ generation) and changes in growth rate between $1^{\text {st }}$ and $4^{\text {th }}$ generation crabs were analysed. Ways to use the research data to manage the blue swimming crab fishery more sustainably were also considered.

\section{Materials and Methods}

This study was conducted from October 2015 to March 2016. Blue swimming crab seed (larvae) were produced at the Hasanuddin University educational hatchery, and grown-out in brackish-water ponds belonging to the South Sulawesi Province Research Development Agency, located in Barru Regency. RAPD analysis was carried out at the Science Building, Faculty of Mathematics and Science, Hasanuddin University, Makassar, South Sulawesi, Indonesia.

Broodstock Collection. Wild crab broodstock were collected from Makassar Strait crab fishermen, and domesticated crab broodstock $\left(3^{\text {rd }}\right.$ generation undergoing selection for fast growth) were collected from the Hasanuddin University experimental pond in Bojo Village, Barru Regency, South Sulawesi Province, Indonesia. Male and female crabs were transported to the Hasanuddin University hatchery using plastic buckets equipped with aerators. The candidate broodstock were then held and prepared for spawning in a 2-ton volume concrete tank equipped with a sand substrate. The tanks were aerated until the crabs spawned. Broodstock were given a commercial feed formulation containing marine worms, sardines, and squid. Feed was provided ad libitum twice a day.

Hatching and Larval Rearing. Hatching took place in a concrete tank (1000 L volume). After the eggs hatched, the broodstock were removed and transferred back to the broodstock pond. The larvae were transferred to a larval rearing tank. During rearing, larvae were fed rotifers, artemia nauplii, and artificial feed. The rearing tank water was maintained at a temperature of 30-32 ${ }^{\circ} \mathrm{C}$, with salinity $31-33 \mathrm{ppt}$, and dissolved oxygen 4.5 ppm. Shelter in the form of plastic tape was placed in the rearing tank when the larvae entered the megalopa stage. Seed were harvested when the larvae reach the Crab-5 stage (after 5 days) with a carapace width of around $5 \mathrm{~mm}$.

Grow out. Crab seed (crablets) were grown out in brackish-water ponds for 100 days, with a stocking rate of $1 / \mathrm{m}^{2}$. Seaweed was scattered into the ponds before the crab seed were stocked at a rate of $1 \mathrm{~kg} / \mathrm{m}^{2}$. Seaweed was used as a shelter by the crablets. During grow out, the crablets were fed with fish at $2 \%$ dry weight per day. Feeding took place twice a day (every morning and evening).

Selective breeding. The selection method used was an individual $/ \mathrm{mass}$ method following the instructions of Tave (1995). Prospective brood stock were collected from several populations to form a brood stock base population in order to obtain larvae (crablets). The crablets from different individuals within the population were pooled (mixed together) and grown out in ponds for 3 months before undertaking the selection of individuals with above-average growth. The selected (fastest growing) individuals were then maintained as prospective broodstock for the next generation. Performance, especially growth, was analysed as an indicator of the increase in genetic potential due to this selection process. This increase can also be called the "genetic gain" of the crabs produced (Figure 1). 


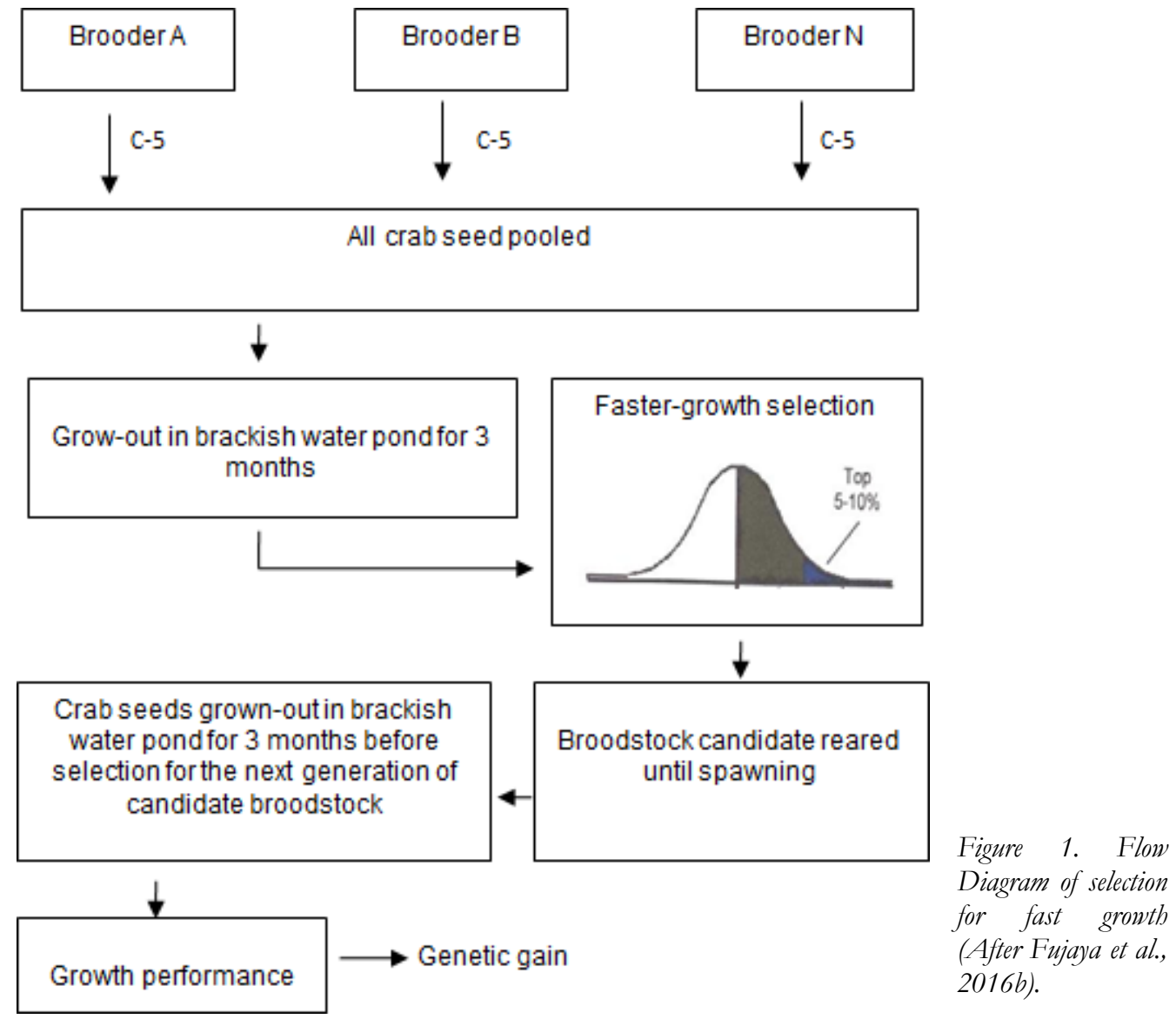

RAPD Analysis. The Random Amplification of Polymorphic DNA (RAPD) analysis was carried out on the $1^{\text {st }}$ and $4^{\text {th }}$ generations of domesticated crabs selected for fast growth. The process comprised 4 main stages: 1) collection of tissue samples; 2) genomic DNA extraction; 3) RAPD-PCR Assay; and 4) analysis of the DNA bands formed.

Tissue samples (claw muscle tissue) for the RAPD analysis were collected from the claws of surviving male crabs after grow-out in ponds for 100 days. The blue swimming crab samples could be divided into 4 groups, namely: G1B (1 ${ }^{\text {st }}$ generation, big size), G1S (1 ${ }^{\text {st }}$ generation, small size), G4B (4th generation, big size), and $\mathrm{G} 4 \mathrm{~S}$ (4th generation, small size). The crabs were anaesthetised with ice water at $8^{\circ} \mathrm{C}$ before claw tissue (meat) removal. Each sample was placed in a labelled bottle filled with $70 \%$ ethanol.

Genomic DNA extraction followed the Geneaid Tissue DNA Extraction method. The process comprised the following steps: firstly, $30 \mathrm{mg}$ of tissue sample was placed in an Eppendorf tube, then $200 \mu \mathrm{L}$ GT buffer and $20 \mu \mathrm{L}$ Proteinase K were added. The tissue sample was crushed using a Microprestel and then incubated at $60^{\circ} \mathrm{C}$ for 30 minutes. After adding $200 \mu \mathrm{l}$ GBT buffer, the tube was then vortexed for 5 seconds and reincubated at $60^{\circ} \mathrm{C}$ for 20 minutes until all lysates were destroyed. After incubation, $200 \mu l$ of pure ethanol was added followed by vortexing for 10 seconds and transfer to a genomic DNA (GD) column and centrifuging for 2 minutes at 16,000 G. Each sample 
was then washed three times. During each wash, the supernatant was transferred to a collecting tube and placed in a GD column to which wash buffer was added (first wash $400 \mu \mathrm{L}$, second and third washes $600 \mu \mathrm{L}$ ) followed by centrifuging at 16,000 G for 30 seconds. After the third wash, the GD column was transferred to a new Eppendorf tube, to which $100 \mu \mathrm{L}$ of pre-heated elution buffer was added and allowed to stand for 5 minutes before centrifuging at $16,000 \mathrm{G}$ for 30 seconds. The eluted DNA in the Eppendorf tube was then ready for PCR.

Five universal primers were used for the RAPD-PCR assay. These were the five primers in the Operon Technology Kit A (OPA) (Table 1). A M100bp DNA ladder was also used to calibrate the results.

Table 1. Primers and primer sequences used for the detection of polymorphism in domesticated blue swimming crabs

\begin{tabular}{cccc}
\hline No & Primer & Sequence & GC content $(\%)$ \\
\hline 1 & OPA-2 & AGG GGT CTT G & 60,0 \\
2 & OPA-5 & TCT GTG CTGG & 60,0 \\
3 & OPA-11 & CAA TCG CCG T & 60.0 \\
4 & OPA-14 & TCT GTG CTGG & 60.0 \\
5 & OPA-17 & GAC CGC TTG T & 60,0 \\
\hline
\end{tabular}

DNA amplification reactions were carried out after DNA cleaning using PuReTaq RTGPCR beads (GE healthcare). PCR was carried out on a PCR GeneAmp System 2700 (Applied Biosystems) unit programmed for 45 cycles. Each PCR reaction tube contained a total volume of $25 \mu \mathrm{L}$, comprised of $1 \mu \mathrm{L}$ primer $(50 \mathrm{pmol} / \mu \mathrm{L}), 3 \mu \mathrm{L}$ DNA template, and $21 \mu \mathrm{L}$ water free RNAse mix. The PCR thermocycler was programmed for 45 cycles of 94 ${ }^{\circ} \mathrm{C}$ for $30 \mathrm{sec}, 36{ }^{\circ} \mathrm{C}$ for $30 \mathrm{sec}$, and $72{ }^{\circ} \mathrm{C}$ for $1 \mathrm{~min}$. An initial denaturation step of $2 \mathrm{~min}$ at $94^{\circ} \mathrm{C}$ and a final extension step of $2 \mathrm{~min}$ at $72{ }^{\circ} \mathrm{C}$ were included in the first and last cycles, respectively.

The PCR products were separated through electrophoresis on $2.0 \%$ agarose gel in a $1 \mathrm{x}$ TBE buffer solution for 1.5 hours at 150 volts. Agarose gel $(0.8 \%)$ was made through heating a solution of $0.24 \mathrm{~g}$ agarose in $30 \mathrm{ml}$ of $1 \mathrm{x}$ TBE buffer until clear, then pouring the liquid gel into mould with a comb to form wells for loading PCR product. A $3 \mu \mathrm{L}$ volume of migrated PCR product was taken and mixed with $1.0 \mu \mathrm{L}$ loading dye, and inserted into each electrophoresis well. Electrophoresis in 1x TBE buffer at 150 Volt with a current strength of $75 \mathrm{~mA}$ was run until the DNA had migrated three quarters of the length of the gel from the negative pole towards the positive pole. The gel was then stained with ethidium bromide at a concentration of $0.5 \mathrm{ng} / \mathrm{mL}$. DNA electrophoresis results were visualized under ultra-violet (UV) light and documented by a digital documentation system connected to a computer using a proprietary program.

\section{Statistical Analysis}

Growth performance was measured as an indicator of the potential for genetic improvement of this crab. Parameters measured were carapace width $(\mathrm{CW})$ and growth rate. The $\mathrm{CW}$ was measured as the distance between the tips of the anterolateral carapace spines using digital callipers. Growth rate $\left(\mathrm{mm} \mathrm{day}^{-1}\right)$ was calculated as the difference between final (at time t) and initial CW measurements divided by the rearing time: (CWt CWo) $\square \mathrm{t}^{-1}$. Growth rate data were compared using Student's T-test. 
Scoring of RAPD-PCR assay fragments was carried out based on predetermined standard markers to obtain binary data. The presence of fragments was scored as 1 (one) while the absence of fragments was scored as 0 (zero). The UPGMA (Unweighted Pair Group Method of Arithmetic) Dendrogram of the Portunus pelagicus sample groups was constructed based on Nei (1972) from similarity index and genetic distance values, using the computer program Tools For Population Genetic Analyses (TFPGA Ver. 1.3) (Miller, 1997).

\section{Results and Discussion}

\subsection{Results}

The sex ratio (Male:Female) was similar for the first generation (44:56) and fourth generation (45:55). The data on domesticated crab carapace width from the 1 st and 4 th generations show a shift towards the right (larger sizes) in the size distribution for both sexes (Figure 2). These results indicate that there is a change in mean growth rate between the 1 st and 4 th generation. The mean growth rate of the 1 st generation was 1.0 . mm per day while the fourth generation has a faster mean growth rate of $1.1 \mathrm{~mm}$ per day (Table

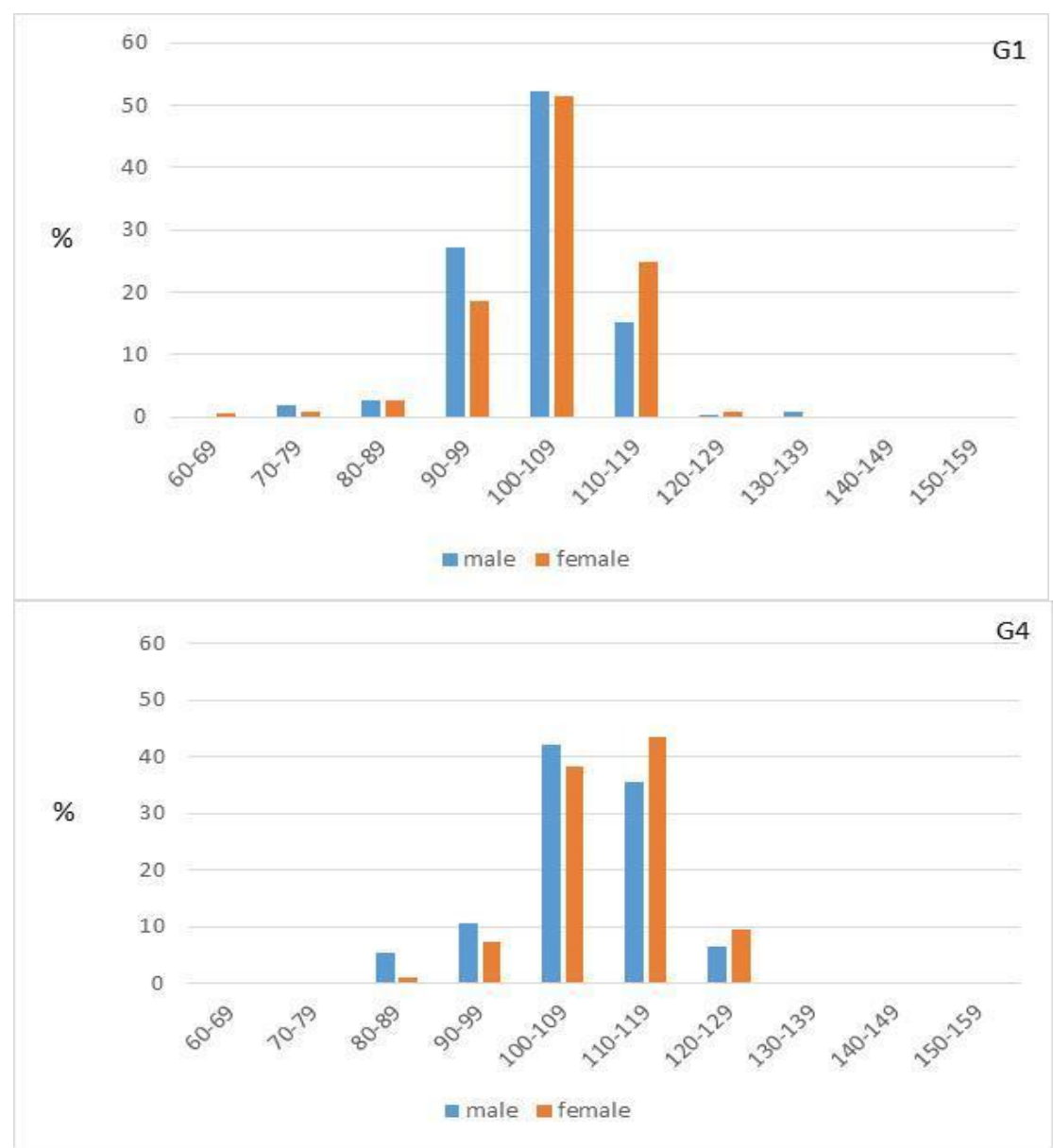

Figure 2. Carapace Width (mm) distribution of 1 st (G1) and 4th generation (G4) domesticated crabs 
Table 2. Growth rate of domesticated crabs after 100 days rearing in ponds

\begin{tabular}{cccc}
\hline Generation & Sex & Growth in Carapace Width $(\mathrm{mm})$ & Growth rate (mm day-1) \\
\hline G1 & Male & 102.0 & 1.0 \\
& Female & 104.1 & 1.0 \\
G4 & Male & 107.8 & 1.1 \\
& Female & 109.8 & 1.1 \\
\hline
\end{tabular}

Harvested crab yields were divided into 4 groups: G1B (1 ${ }^{\text {st }}$ generation, big size; mean CW $=105 \mathrm{~mm}), \mathrm{G} 1 \mathrm{~S}\left(1^{\text {st }}\right.$ generation, small size; mean CW $\left.=90 \mathrm{~mm}\right), \mathrm{G} 4 \mathrm{~B}\left(4^{\text {th }}\right.$ generation, big size; mean $\mathrm{CW}=115 \mathrm{~mm}$ ), and $\mathrm{G} 4 \mathrm{~S}$ (4th generation, small size; mean $\mathrm{CW}=100 \mathrm{~mm}$ ). These four groups were compared using the DNA assay.

The DNA amplification products showed that the universal primer set (OPA) performed well. The OPA-2 primer produced 6-13 fragments DNA with a size of 200-1500 bp; the OPA-5 primer produced 6-8 fragments of 300-900 bp; the OPA-11 primer produced 7-13 fragments of 250-1500 bp; the OPA-14 primer produced 3 fragments of 500-1500 bp; and the OPA-17 primer produced 4-8 fragments of 400-1550 bp. The electrophoresis results from PCR product obtained from $P$. pelagicus DNA using four of the five primers are shown in Figures 3, 4, 5, and 6.

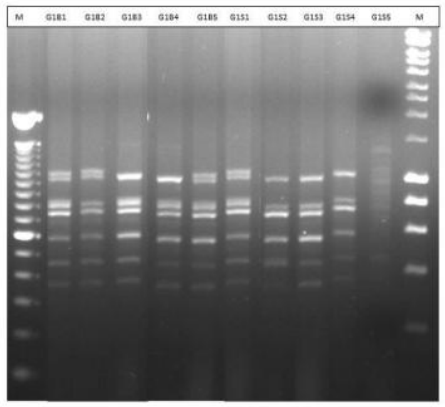

A

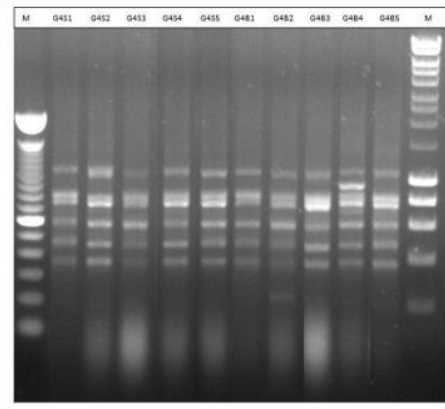

B

Figure 3. OPA-2 Amplified products on $0.8 \%$ agarose gel. Each lane shows an amplified DNA sample from a different individual from 1 st generation (A) and 4 th generation (B) crabs. Marker: $1 \mathrm{~kb}$ molecular weight

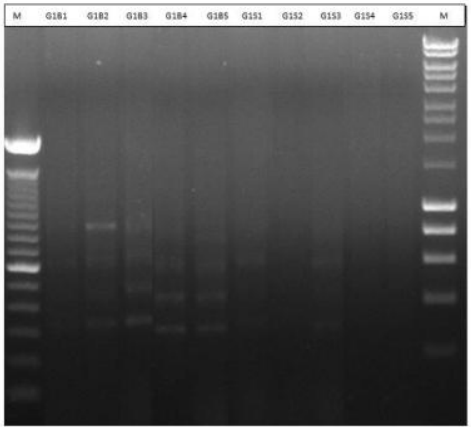

A

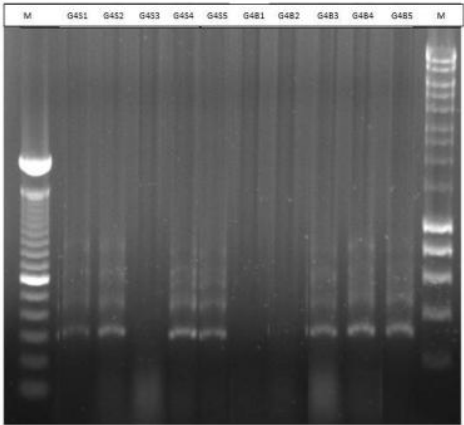

B

Figure 4. OPA-5 Amplified products on 0.8\% agarose gel. Each lane shows an amplified DNA sample from a different individual from 1st generation (A) and 4th generation (B) crabs.. Marker: $1 \mathrm{~kb}$ molecular weight 


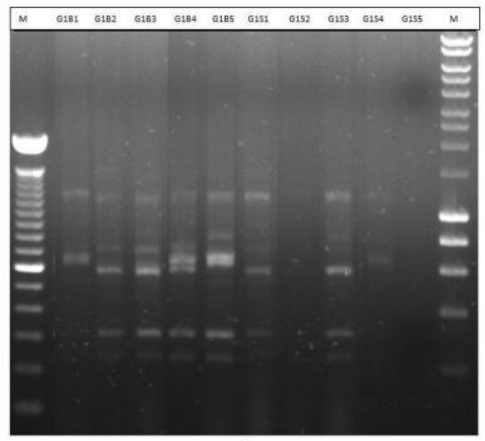

A

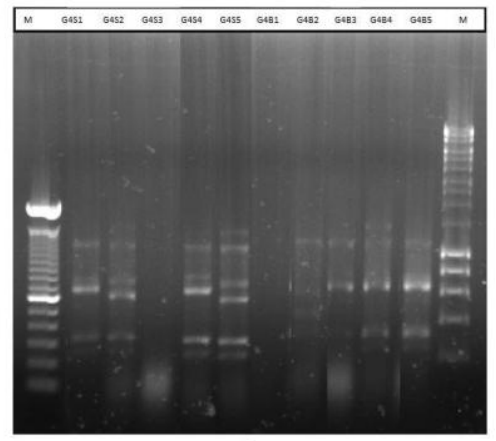

B

Figure 5. OPA-11 Amplified products on 0.8\% agarose gel. Each lane shows an amplified DNA sample from a different individual from 1st generation (A) and 4th generation (B) crabs. Marker: $1 \mathrm{~kb}$ molecular weight

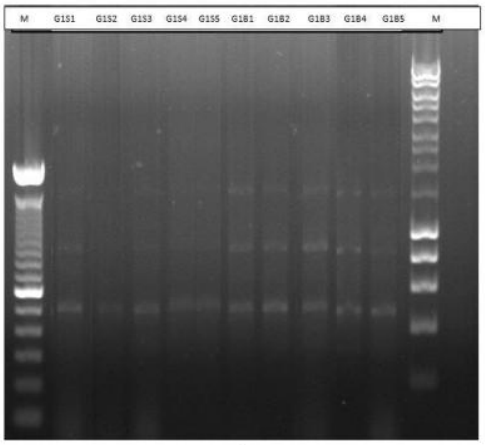

A

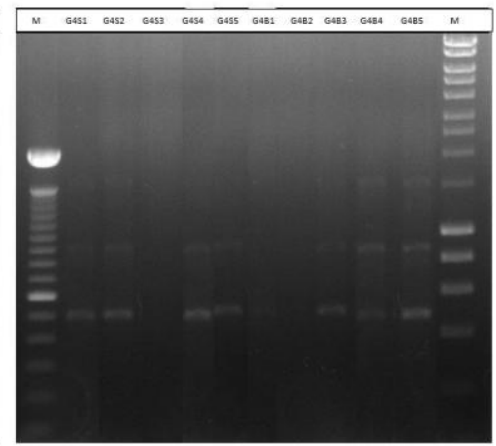

B

Figure 6. OPA-14 Amplified products on 0.8\% agarose gel. Each lane shows an amplified DNA sample from a different individual from 1st generation (A) and 4th generation (B) crabs. Marker: $1 \mathrm{~kb}$ molecular weight

The number of fragments, polymorphic proportions, and fragment size from the five primers combined showed that the G1B (big size from $1^{\text {st }}$ generation) group had 26 fragments with polymorphic proportions of $34.61 \%$; the GiS (small size from $1^{\text {st }}$ generation) group had 21 fragments, 28.57\% polymorphic; the G4B (big size from $4^{\text {th }}$ generation) group had 22 fragments, $40.9 \%$ polymorphic; and the G4S (small size from 4th generation) group had 25 fragments, 36\% polymorphic. Overall, the four groups produced fragments varying in size from $250-1550 \mathrm{bp}$. These data were used to analyse the similarity index and genetic distance.

The similarity index and the genetic distances between the four groups (G1B, G1S, G4B, and G4S) indicate significant differences between the G4B group and the other three groups (Tables 3 and 4). The dendrogram using RAPD markers showed two clusters (Figure 7).

Table 3. Similarity Index of $P$. pelagicus groups

\begin{tabular}{ccccc}
\hline Pop. ID & G1B & G1S & G4B & G4S \\
\hline G1B & 1.00 & & & \\
G1S & 0.95 & 1.00 & & \\
G4B & 0.74 & 0.68 & 1.00 & \\
G4S & 0.95 & 0.89 & 0.79 & 1.00 \\
\hline
\end{tabular}


Table 4. Genetic Distance between P. pelagicus groups

\begin{tabular}{ccccc}
\hline Pop. ID & G1B & G1S & G4B & G4S \\
\hline G1B & 0.000 & & & \\
G1S & 0.0527 & 0.000 & & \\
G4B & 0.2632 & 0.3158 & 0.000 & \\
G4S & 0.0527 & 0.1053 & 0.2106 & 0.000 \\
\hline
\end{tabular}
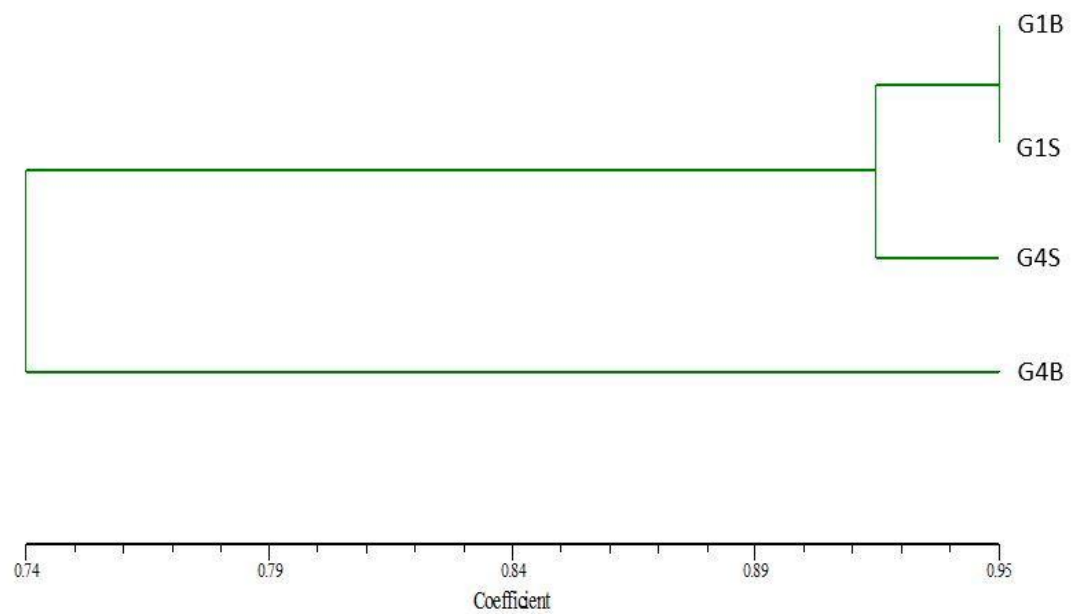

Figure 7. Dendrogram based on Nei's (1972) Genetic distance; UPGMA Method; G1 (1 $1^{\text {st }}$ generation); G4 (4 ${ }^{\text {th }}$ generation); B big sample; $S$ small sample

\subsection{Discussion}

Doyle (1983) argues that domestication selection is defined as natural selection in traits that affect survival and reproduction in a human (domestic) controlled environment. Growth rates, disease resistance, tolerance of a given environment, and ability to utilize feed are among the most common targets of selection (Liao and Huang (2000). Wellenreuther et al (2019) found pronounced growth and gene expression differences between wild and domesticated individuals related to global developmental and immune pathways. Temperature-modulated growth responses were linked to major pathways affecting metabolism, cell regulation and signalling. In this study, domestication with selection for rapid growth carried out on the blue swimming crab succeeded in increasing growth performance and resulted in changed genetic distance.

Each animal has a different response to domestication selection. Gjedrem (2016) reports various genetic benefits obtained from large aquaculture breeding programs. For example, in Nile tilapia (Oreochromis niloticus) growth rate was doubled after 6-7 generations of selection. Growth rates of Atlantic salmon (Salmo salar) in Norway more than doubled after 5 generations of selection for rapid growth. The response was also positively correlated for protein and energy retention so that the FCR was reduced by $23 \%$. Genetic benefits are also reported for several diseases such as resistance to pancreatic necrosis (IPN) and Vibrio salmonicida infection. However, Solberg et al., (2013) suggested that domestication could lead to reduced or increased genetic variation in salmon, with a decline in genetic variation increasing susceptibility to diseases and predators in salmon 
farms. Trut et al. (2009) describe changes in behaviour, morphology and physiology that appeared during selection for tameness, similar to those observed in the domestic dog. Continued evaluation and interpretation of genetic variation during commercial cultivation on the same species in different environments is important, so that the goals of domestication and the main targets of breeding programs can be achieved. Domesticated populations are susceptible to inbreeding, which is likely to result in an increase homozygote, with potential negative impacts on fitness and traits important for aquaculture. Therefore, it is not always recommended to continue to conduct domestication selection for economically important traits. Cross breeding can be important to re-increase heterozygote and genetic variation in cultivated populations of a species. The results of the Goyard et al (2008) study give good examples of improvements in performance with effects and/or heterosis resulting from cross breeding, as well as loss of performance from inbreeding. They show that the aquaculture industry can benefit from the use of two different strains to produce F1 hybrids in commercial cultivation. An increase in growth performance was observed, although it was not as large or significant as that obtained through selective breeding in salmon and tilapia (Gjedrem et al., 2016). The data from this study indicate that the blue swimming crab shows good prospects for development as an aquaculture commodity to supply the increasing world market demand. Trijuno et al. (2015) also reported that domesticated blue swimming crab broodstock could produce superior offspring with higher survival rate, faster larval stage changes and more uniform larval growth compared to larvae from wild brood stock. This study showed that the use of domesticated blue swimming crab broodstock can also improve crablet and juvenile crab grow-out performance.

Four possible scenarios are suggested for the future of sustainable blue swimming crab fisheries, making use of blue swimming crab breeding and culture technology. These are as follows: 1) to develop a blue swimming crab aquaculture industry that focuses on brood stock domestication, similar to the path taken by agriculture but avoiding the negative impacts of captive breeding by continuing to evaluate and control genetics; 2) to restock wild populations with blue swimming crab seed obtained from natural (wild-caught) brood stock; 3) scientists and aquaculture organizations could inform farmers about the great benefit of using genetically improved stocks; and 4) government should stimulate as well as financially support the establishment of breeding programs and restocking.

\section{Conclusion}

Domestication followed by selection for fast growth resulted in a change in genomic DNA characters associated with the positive trait of faster growth. Domestication with selection for fast growth can be used to produce domesticated blue swimming crab broodstock which will produce offspring with higher growth rates. Domestication with selection for fast growth as carried out under this study can still be continued past the $4^{\text {th }}$ generation (G4), because genetic variation in the G4 population is still quite high.

\section{Acknowledgements}

The authors wish to thank the Ministry of Education and Culture, Republic of 
Indonesia, for funding this research through a grant under the Excellent National Strategic Research scheme. In-kind support provided by the Faculty of Marine Sciences and Fisheries, Hasanuddin University and by the Research Development Agency, South Sulawesi Province, is gratefully acknowledged.

\section{References}

Doyle RW. 1983. An approach to the quantitative analysis of domestication selection in aquaculture. Aquaculture, 33(1-4): 167-185

Fujaya Y., Asphama AI., Hidayani AA., Parenrengi A., Tenriulo A. 2016a. High genetic variation of Portunus pelagicus from Makassar Straits revealed by RAPD markers and mitochondrial 16S rRNA sequences. African Journal of Biotechnology, 15(7): 180-190

Fujaya Y., Trijuno DD., Aslamyah S., Alam N. 2016b. Domestication and selective breeding for producing fast growing and high meat quality of blue swimming crab (Portunus pelagicus). AACL Bioflux, 9 (3): 670-679

Gjedrem T. 2016. The Benefit of Using Selective Breeding for Aquatic Species. Ann Aquac Res 3(2): 1021

Goyard E., Goarant C., Ansquer D., Brun P., de Decker S., Dufour R., Galinié C., Peignon J-M., Pham D., Vourey E., Harache Y., Patrois J. 2008. Cross breeding of different domesticated lines as a simple way for genetic improvement in small aquaculture industries: Heterosis and inbreeding effects on growth and survival rates of the Pacific blue shrimp Penaeus (Litopenaeus) stylirostris. Aquaculture, 278(1-4): 43-50

Hidayani AA., Fujaya Y., Asphama AI , Trijuno DD., Tenriulo A., Parenrengi A. 2015. The Morphometric Character and Mitochondrial 16S rRNA Sequence of Portunus pelagicus. Aquacultura Indonesiana. 16 (1) : 1-9

Johnston D., Harris D., Caputi N., Thomson A., 2011 Decline of a blue swimmer crab (Portunus pelagicus) fishery in Western Australia - history, contributing factors and future management strategy. Fisheries Research 109:119-130

Kunsook C, Gajaseni N., Paphavasit N. 2014. A Stock Assessment of the Blue Swimming Crab Portunus pelagicus (Linnaeus, 1758) for Sustainable Management in Kung Krabaen Bay, Gulf of Thailand. Tropical Life Sciences Research, 25(1), 41-59

La Sara, Muskita WH., Astuti O., Safilu. 2017. Some population parameters of blue swimming crab (Portunus pelagicus) in Southeast Sulawesi waters, Indonesia. AACL Bioflux. 10(3):587-601.

Liao IC., Huang YS. 2000.Methodological approach used for the domestication of potential candidates for aquaculture. Recent advances in Mediterranean aquaculture finfish species diversification. Zaragoza : CIHEAM, 97-107

Miller MP., 1997. Tools for Population Genetic Analyses (TFPGA) version 1.3. A Windows ${ }^{\circledR}$ program for the analysis of allozyme and molecular population genetic data. Department of Biological Sciences Box 5640 Northern Arizona University Flagstaff, AZ 86011-5640. 30pp.

Nei M. 1972. Genetic distance between populations. American Naturalist 106(949): 283-292

Solberg MF., Skaala Ø., Nilsen F., Glover KA. 2013. Does Domestication Cause Changes in Growth Reaction Norms? A Study of Farmed, Wild and Hybrid Atlantic Salmon Families Exposed to Environmental Stress. PLOS ONE, 8(1):1-11

Tave D., 1995 Selective breeding programmes for medium-sized fish farms. FAO Fisheries Technical Paper No. 352, Rome, Italy, 122 pp.

Trijuno DD., Fujaya Y, Agviranti, Marhama S. 2015. Quality of Blue swimming crab Portunus pelagicus Larvae from Domesticated Broodstock. Aquacultura Indonesiana, 16 (1) : 22-28

Trut L., Oskina I., Kharlamova A. 2009. Animal evolution during domestication: the domesticated fox as a model. Bioessays, 31(3): 349-360.

Wellenreuther M., Le Luyer J., Cook D., Ritchie PA., Bernatchez L. 2019. Domestication and Temperature Modulate Gene Expression Signatures and Growth in the Australasian Snapper Chrysophrys auratus. G3 Genes Genomes Genetics. 9:105-116 